Check for updates

Cite this: RSC Adv., 2017, 7, 41495

Received 11th March 2017

Accepted 27th June 2017

DOI: 10.1039/c7ra02951a

rsc.li/rsc-advances

\section{New alkaloids with unusual spermidine moieties from the seeds of Orychophragmus violaceus and their cytoprotective properties $\uparrow$}

\author{
Nailiang Zhu, (D) $\ddagger^{a}$ Haifeng Wu, $\ddagger^{a}$ Ziqian Xu, ${ }^{b}$ Chenqi Liu, ${ }^{a}$ Yu Tian, ${ }^{a}$ Meigeng Hu, ${ }^{a}$ \\ Zhong Hao Sun, ${ }^{a}$ Pengfei Li, ${ }^{a}$ Guoxu Ma*a and Xudong Xu*a
}

The seeds of the plant Orychophragmus violaceus yielded eight new spermidine alkaloids, termed orychophragmuspine A-H (1-8). Their structures were elucidated by extensive spectroscopic analysis and comparison with literature data. Compounds 1-8 are unusual natural alkaloids with spermidine moieties and were tested for cytoprotective properties. The results showed that all compounds displayed mild cytoprotective activities compared with the normal and model groups.

\section{Introduction}

Orychophragmus violaceus (L.) (Brassicae) is mainly distributed in Eastern China and Korea and is cultivated as an ornamental plant in China. ${ }^{1}$ In addition, it is gathered for its use as a wild vegetable in some regions. ${ }^{2-5}$ Previous chemical and pharmacological studies on the stems of this plant resulted in the isolation of flavonoids, amino acids, fatty acids and phenolic acids, which showed antioxidative, anti-inflammatory, antidiabetic, antitumor and hepatoprotective effects. ${ }^{6-12}$

Despite their popular use, there have been no chemical or pharmaceutical studies available on $O$. violaceus seeds until now. ${ }^{11}$ Our previous bioactivity screening showed that the aqueous extract of $O$. violaceus seeds displayed significant hepatoprotective activity in vivo, which urged us to further investigate secondary metabolites of seeds. ${ }^{12}$ In our ongoing search for bioactive constituents, eight new alkaloids with unusual spermidine moieties, orychophragmuspine A-H (1-8) were isolated and characterized (Fig. 1). Herein, the isolation and structural elucidation of the new compounds as well as the evaluation of their cytoprotective properties are described (Fig. 2).

${ }^{a}$ Key Laboratory of Bioactive Substances and Resource Utilization of Chinese Herbal Medicine, Ministry of Education, Beijing Key Laboratory of Innovative Drug Discovery of Traditional Chinese Medicine (Natural Medicine) and Translational Medicine, Key Laboratory of Efficacy Evaluation of Chinese Medicine against Glycolipid Metabolic Disorders, State Administration of Traditional Chinese Medicine, Institute of Medicinal Plant Development, Peking Union Medical College and Chinese Academy of Medical Sciences, Beijing 100193, China. E-mail: mgxfl8785@163.com; xdxu@implad.ac.cn; Fax: +86 10 57833296; Tel: +86 10 57833296

${ }^{b}$ School Public Health, Peking University, Beijing 100191, China

$\dagger$ Electronic supplementary information (ESI) available. See DOI: 10.1039/c7ra02951a

\$ These authors contributed equally to this article.

\section{Results and discussion}

Compound 1 was obtained as an amorphous white solid and reacted positively to Dragendorff's reagent. Its molecular formula was determined to be $\mathrm{C}_{26} \mathrm{H}_{33} \mathrm{~N}_{3} \mathrm{O}_{5}$ by HRESIMS. The IR spectrum displayed absorptions at $1652 \mathrm{~cm}^{-1}$ for $\beta$-unsaturated amides and 1537 and $1504 \mathrm{~cm}^{-1}$ for aromatic rings. The UV spectrum displayed maximum absorption bands at 233.0 and $287.6 \mathrm{~nm}$. The ${ }^{1} \mathrm{H}$ NMR spectrum of compound 1 (Table $\mathrm{S} 1 \dagger$ ) showed two typical ABX systems at $\delta_{\mathrm{H}} 6.89(1 \mathrm{H}, \mathrm{d}, J=8.4 \mathrm{~Hz}), 7.38(1 \mathrm{H}, \mathrm{d}, J=1.2 \mathrm{~Hz})$, $7.18(1 \mathrm{H}, \mathrm{dd}, J=8.4,1.2 \mathrm{~Hz})$ and $\delta_{\mathrm{H}} 6.75(1 \mathrm{H}, \mathrm{d}, J=7.8 \mathrm{~Hz}), 6.08$

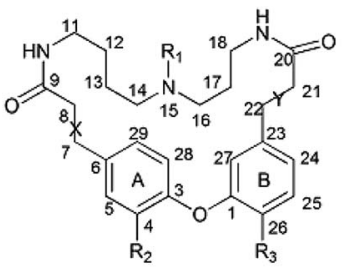<smiles>[R]CCCCCNC(=O)C=Cc1ccc([R3])c(Oc2ccc([X]C(=O)NCCCNC([R])C)cc2[R2])c1</smiles>

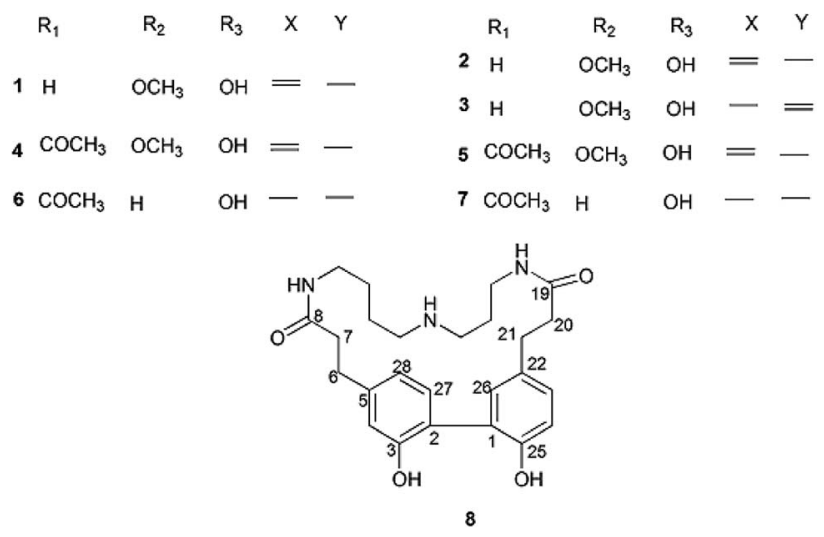

Fig. 1 Structures of compounds 1-8. 


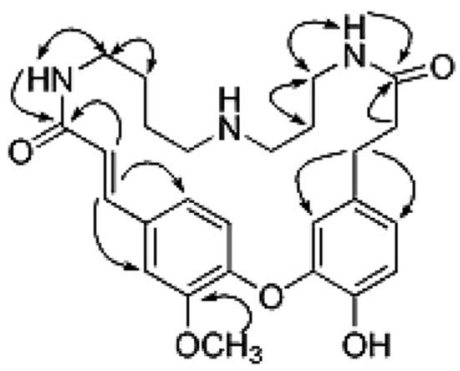

Fig. 2 Key ${ }^{1} \mathrm{H}-{ }^{1} \mathrm{H}$ COSY (bond) and HMBC (arrows) correlations for compound 1.

$(1 \mathrm{H}, \mathrm{d}, J=1.2 \mathrm{~Hz}), 6.62(1 \mathrm{H}, \mathrm{dd}, J=7.8,1.2 \mathrm{~Hz})$, suggesting the existence of two 1,2,4-trisubstituted benzene rings. The spectrum also contained resonance signals at $\delta_{\mathrm{H}} 7.44(\mathrm{~d}, 1 \mathrm{H}, J=15.6$ $\mathrm{Hz}$ ) and $6.77(\mathrm{~d}, 1 \mathrm{H}, J=15.6 \mathrm{~Hz})$ which were assigned to a double bond in the $E$ configuration, and resonances at $\delta_{\mathrm{H}} 2.62$ $(2 \mathrm{H}, \mathrm{m})$ and $2.09(\mathrm{~m}, 2 \mathrm{H})$ due to two methylene protons. The following resonances were also observed: $\delta_{\mathrm{H}} 3.80\left(3 \mathrm{H}, \mathrm{s}, \mathrm{OCH}_{3}\right)$, $\operatorname{six} \delta_{\mathrm{H}} 6.89(1 \mathrm{H}, \mathrm{d}, J=8.4 \mathrm{~Hz}, \mathrm{H}-28), \delta_{\mathrm{H}} 6.08(1 \mathrm{H}, \mathrm{d}, J=1.2 \mathrm{~Hz}, \mathrm{H}-$ 27), $\delta_{\mathrm{H}} 6.62(1 \mathrm{H}, \mathrm{d}, J=7.8,1.2 \mathrm{~Hz}, \mathrm{H}-24), \delta_{\mathrm{H}} 6.75(\mathrm{~d}, 1 \mathrm{H}, J=$ $7.8 \mathrm{~Hz}, \mathrm{H}-25), \delta_{\mathrm{H}} 7.38(1 \mathrm{H}, \mathrm{d}, J=1.2 \mathrm{~Hz}, \mathrm{H}-5), \delta_{\mathrm{H}} 7.18(1 \mathrm{H}, \mathrm{dd}, J$ $=8.4,1.2 \mathrm{~Hz}, \mathrm{H}-29)$. The ${ }^{13} \mathrm{C}$ APT NMR spectrum of compound 1 displayed 6 carbon resonances including $\delta_{\mathrm{C}} 122.7$ (C-24), 116.1 (C-25), 114.9 (C-27), 112.3 (C-5), 121.8 (C-28) and 120.7 (C-29). The ${ }^{1} \mathrm{H}$ and ${ }^{13} \mathrm{C}$ NMR spectroscopic data of compound 1 confirmed that the compound was a spermidine alkaloid derivative. ${ }^{13-16}$ An HMBC experiment was performed to establish the location of functional groups and the full structure of compound 1. Long-range $\mathrm{HMBC}$ correlation between $\delta_{\mathrm{H}} 7.44$ $(1 \mathrm{H}, \mathrm{d}, J=15.6 \mathrm{~Hz})$ and $\delta_{\mathrm{C}} 112.3$ (C-5) and 120.7 (C-29) suggested the $(E)$-olefin was attached to the 1,2,4-trisubstituted benzene ring A. HMBC cross-peaks between methylene protons at $\delta_{\mathrm{H}} 2.62(2 \mathrm{H}, \mathrm{m})$ and $\delta_{\mathrm{C}} 114.9(\mathrm{C}-27)$ and $122.7(\mathrm{C}-24)$ confirmed that the methylene was adjacent to the 1,2,4-trisubstituted benzene ring $\mathrm{B}$. HMBC correlation of the $\mathrm{OCH}_{3}$ at $\delta_{\mathrm{H}}$ 3.80 with $\mathrm{C}-4\left(\delta_{\mathrm{C}} 151.3\right)$ suggested this $\mathrm{OCH}_{3}$ was attached to C4. In addition, the HMBC spectra showed that the $(E)$-olefinic proton at $\delta_{\mathrm{H}} 6.77$ and the amide proton at $\delta_{\mathrm{H}} 8.37(\mathrm{brs}, 1 \mathrm{H})$ were correlated with a carboxyl carbon at $\delta_{\mathrm{C}} 165.4$ and that methylene protons at $\delta_{\mathrm{H}} 2.09$ and the amide proton at $\delta_{\mathrm{H}} 7.82(\mathrm{brs}, 1 \mathrm{H})$ were correlated with a carboxyl carbon at $\delta_{\mathrm{C}} 171.1$, allowing the resonances at $\delta_{\mathrm{H}} 8.37(\mathrm{brs}, 1 \mathrm{H})$ and $7.82(\mathrm{brs}, 1 \mathrm{H})$ to be assigned to $\mathrm{H}-10$ and $\mathrm{H}-19$, respectively. ${ }^{1} \mathrm{H}^{-1}{ }^{1} \mathrm{H}$ COSY spectra indicated that the methylene protons at $\delta_{\mathrm{H}} 3.28(2 \mathrm{H}, \mathrm{m}, \mathrm{H}-11)$ were coupled with the amide proton on $\mathrm{N}-10$ at $\delta_{\mathrm{H}} 8.37(1 \mathrm{H}, \mathrm{brs})$ as well as with methylene signals at $\delta_{\mathrm{H}} 1.57(2 \mathrm{H}, \mathrm{m}, \mathrm{H}-12)$. Downfield signal at $\delta_{\mathrm{H}} 2.80(2 \mathrm{H}, \mathrm{m}, \mathrm{H}-14)$ coupled with $\delta_{\mathrm{H}}$ $1.60(2 \mathrm{H}, \mathrm{m}, \mathrm{H}-13)$ indicated that the methylene on $\mathrm{C}-14$ was attached at $\mathrm{N}-15$. In addition, the ${ }^{1} \mathrm{H}-{ }^{1} \mathrm{H}$ COSY spectrum indicated that the methylene protons at $\delta_{\mathrm{H}} 2.61(2 \mathrm{H}, \mathrm{m}, \mathrm{H}-18)$ were coupled with the amide proton on $\mathrm{N}-19$ at $\delta_{\mathrm{H}} 7.82(1 \mathrm{H}, \mathrm{brs})$ as well as the methylene signal at $\delta_{\mathrm{H}} 1.56(2 \mathrm{H}, \mathrm{m}, \mathrm{H}-17)$. Downfield signal at $\delta_{\mathrm{H}} 2.58(\mathrm{~m}, 2 \mathrm{H}, \mathrm{H}-16)$ coupled with $\delta_{\mathrm{H}} 1.56(\mathrm{~m}, 2 \mathrm{H}, \mathrm{H}-$ $17)$, indicating that the methylene on $\mathrm{C}-16$ was attached to $\mathrm{N}-15$. The $\mathrm{H}_{2}-11$ was determined to be the terminal methylene group of the $\left(\mathrm{CH}_{2}\right)_{4}$ portion of spermidine, attached to $\mathrm{N}(10) \mathrm{H}$, and the HMBC correlation of $\mathrm{N}(10) \mathrm{H}$ with the carboxyl $\mathrm{C}$ atom C-9 showed that the $\mathrm{C}_{4}$-unit was connected to ring A. Analogously, the linking of the $\mathrm{C}_{3}$-unit to the carboxyl $\mathrm{C}$ atom $\mathrm{C}-20$, starting from $\mathrm{C}(18) \mathrm{H}_{2}$ via $\mathrm{N}(19) \mathrm{H}$, was likely. The exact attachment of the spermidine moiety to the rest of the molecule was confirmed according to the ${ }^{1} \mathrm{H}-{ }^{1} \mathrm{H}$ COSY and HMBC spectra. The relative stereochemistry of compound $\mathbf{1}$ was resolved by analysis of NOESY spectrum. In the NOESY spectrum, a weak cross peak was found for the protons of $\delta_{\mathrm{H}} 6.08(\mathrm{H}-27)$ and $6.89(\mathrm{H}-28)$, indicating the proximity of these two groups, which confirmed $\mathrm{C}(1)-\mathrm{O}-\mathrm{C}(3)$ linkages. Based on the above results, the structure of compound 1 was established as shown and named orychophragmuspine A (Fig. 1). Compound 1 is representative of a new alkaloid skeleton with a spermidine moiety between C-9 and C-20 (Fig. 3).

Compound 2 was obtained in the form of an amorphous white solid. Its molecular formula $\mathrm{C}_{26} \mathrm{H}_{33} \mathrm{~N}_{3} \mathrm{O}_{5}$ was deduced by HRESIMS $\left(m / z 468.2487[\mathrm{M}+\mathrm{H}]^{+}\right)$. A direct comparison of the NMR data (Table $\mathrm{S} 1 \dagger$ ) between compounds 2 and $\mathbf{1}$ showed that they were isomeric with differences in the spermidine units. Contrary to compound $\mathbf{1}$, a reversed orientation of the spermidine group was shown in compound 2. $\mathrm{C}(11) \mathrm{H}_{2}$, which was correlated to C- 9 as above, was shown to belong to the $\mathrm{C}_{3}$-unit by COSY data, while $\mathrm{C}(18) \mathrm{H}_{2}$, the terminal methylene group of the $\left(\mathrm{CH}_{2}\right)_{4}$ moiety, was linked to the carboxyl C atom C-20. On the basis of the above results, the structure of compound 2 was elucidated and named orychophragmuspine B (Fig. 1).

Compound 3 was a water-soluble amorphous white solid, possessing the same molecular formula as compound 2, as determined through NMR data and an HRESIMS $[\mathrm{M}+\mathrm{H}]^{+}$ion at $m / z$ 468.2481. A comparison of the NMR spectroscopic data of compound 3 with those of compound 2 (Table $\mathrm{S} 1 \dagger$ ) revealed that the main differences between them were the $(E)$-olefinic protons at $\delta_{\mathrm{H}} 6.55$ and 7.36 at $\mathrm{C}-21$ and $\mathrm{C}-22$ in compound 3 rather than at $\mathrm{C}-7$ and $\mathrm{C}-8$ in compound 2. In the HMBC spectrum, the correlations from $\mathrm{H}-21(6.55)$ and $\mathrm{H}-22(7.36)$ to $\delta_{\mathrm{C}}(\mathrm{C}-20)$ and $\delta_{\mathrm{C}}$ (C-23), together with the ${ }^{1} \mathrm{H}^{1}{ }^{1} \mathrm{H}$ COSY spectrum, confirmed these distinctions. As a result, compound 3 was termed orychophragmuspine C (Fig. 1).

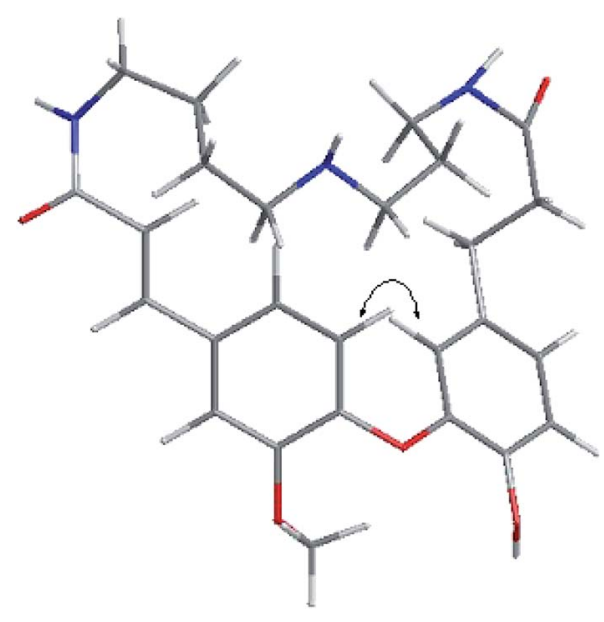

Fig. 3 Key NOESY correlations of compound 1. 
Compounds 4 and $\mathbf{5}$ were isolated as an inseparable mixture of two isomers present in an approximate ratio of $6: 5$. Based on the HRESIMS adduct ion detected at $m / z 532.2413[\mathrm{M}+\mathrm{Na}]^{+}$, the mixture (compounds 4/5) shared the same molecular formula of $\mathrm{C}_{28} \mathrm{H}_{35} \mathrm{~N}_{3} \mathrm{O}_{6}$, requiring thirteen degrees of unsaturation. For the NMR data, most of the signals could be assigned to the two compounds on the basis of the relative intensities or integrals of their signals. However, these two compounds could not be completely separated by any chromatographic methods used in the present study. Fortunately, their spectroscopic data were sufficient for the structural elucidation described below. The ${ }^{1} \mathrm{H}$ and ${ }^{13} \mathrm{C}$ NMR data (Table S2 $\dagger$ ) of compound 4 were similar to those of compound 1 except for the presence of additional acetyl signals at $\delta_{\mathrm{H}} 1.94(3 \mathrm{H}, \mathrm{s}), \delta_{\mathrm{C}} 21.3$ and $\delta_{\mathrm{C}} 172.4$. In the HMBC spectrum, the carbon signal at $\delta_{\mathrm{C}} \mathbf{1 7 2 . 4}$ had long-range correlations with $\mathrm{H}-14\left(\delta_{\mathrm{H}} 3.07\right)$ and $\mathrm{H}-16\left(\delta_{\mathrm{H}} 2.95\right)$ suggesting that the acetyl group was at $\mathrm{N}-15$ in compound 4 . Compound 5 was an isomeric analogue of compound $\mathbf{4}$ with the difference that the $-\mathrm{NH}\left(\mathrm{CH}_{2}\right)_{3}-$ unit was located at $\mathrm{C}-9$ and the $-\mathrm{NH}\left(\mathrm{CH}_{2}\right)_{4}-$ unit was located at C-20. In the $\mathrm{HMBC}$ spectrum, the terminal protons of the spermidine $\mathrm{C}(11) \mathrm{H}_{2}$ and $\mathrm{C}(18) \mathrm{H}_{2}$ correlated to the carboxyl carbons $\mathrm{C}(9)$ and $\mathrm{C}(20)$, respectively, and together with the additional correlations of the amide protons $\mathrm{N}(10) \mathrm{H}$ to the carbons $\mathrm{C}(9) / \mathrm{C}(11)$ and $\mathrm{N}(19) \mathrm{H}$ to the carbons $\mathrm{C}(18) / \mathrm{C}(20)$, supported this assignment. Thus, compounds $\mathbf{4}$ and $\mathbf{5}$ were established as two novel spermidine alkaloids, and named orychophragmuspine D and E, respectively (Fig. 1).

Similar to compounds 4 and 5, compounds 6 and 7 were also an inseparable mixture of two isomers (ratio of $4: 3$ ). The ${ }^{1} \mathrm{H}$ and ${ }^{13} \mathrm{C}$ NMR data (Table S3 $\dagger$ ) of compounds 6 and 7 were similar to those of compounds 4 and 5, except for the disappearance of an $\mathrm{OCH}_{3}$ group at C-4 and (E)-olefinic proton signals at C-7 and C-8 in compounds 6 and 7. In the HMBC spectrum, the additional methylene signals at $\left(\mathrm{H}_{2}-7\right)$ and $\left(\mathrm{H}_{2}-8\right)$ had long-range correlations with C-6 (135.5) and C-9 (173.9). Together with the molecular formula deduced from HRESIMS, this supported the missing functional groups. As a result, the structures of compounds 6 and 7 were elucidated as shown and they were named orychophragmuspine F and G (Fig. 1).

Compound 8 was obtained as an amorphous white solid. The ${ }^{1} \mathrm{H}$ and ${ }^{13} \mathrm{C}$ NMR spectra were closely related to those of compound 1 except for the disappearance of a trans double bond at C-6/C-7 and an ether bond between C-1 and C-2. In the HMBC spectrum, the correlations from aliphatic methylene protons at $\left(\mathrm{H}_{2}-6\right)$ and $\left(\mathrm{H}_{2}-7\right)$ to $\mathrm{C}-5(131.2)$ and C-8 (171.9) indicated that the

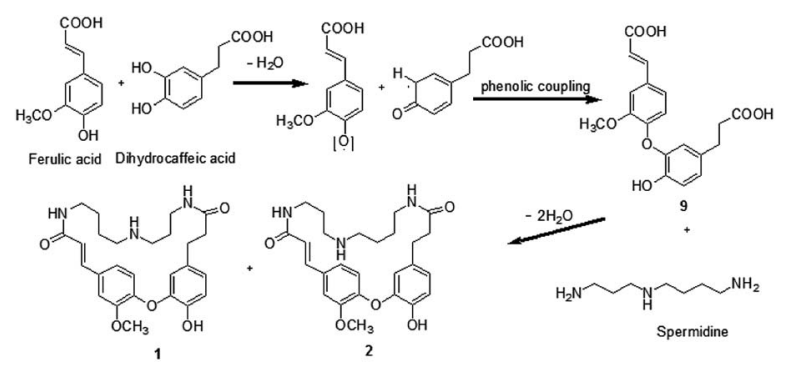

Scheme 1 A proposed biogenetic relationship of compounds 1 and 2 . double bond at C-6/C-7 was hydrogenated. The upfield shifted C-1 (127.0) and C-2 (126.8) in compound 8, in contrast to the C-1 (144.8) and C-3 (145.4) in compound 1, as well as the HMBC correlations from $\mathrm{H}-26\left(\delta_{\mathrm{H}} 6.97\right)$ to $\mathrm{C}-2$, suggested a direct linkage between $\mathrm{C}-1$ and $\mathrm{C}-2$. The molecular formula $\left(\mathrm{C}_{25} \mathrm{H}_{33} \mathrm{O}_{3} \mathrm{~N}_{4}\right)$, together with the upfield carbon signal at (C-3), was evidence for a hydroxyl group at C-3 (154.2) in compound 8 instead of a methoxyl group at C-4 (151.3) in compound 1. Therefore, compound $\mathbf{8}$ was established as a novel spermidine alkaloid and named orychophragmuspine $\mathrm{H}$ (Fig. 1).

A plausible biosynthetic pathway of orychophragmuspine A and B was proposed (Scheme 1). The key intermediate product 9 was produced from ferulic acid and dihydrocaffeic acid by dehydration and a phenolic coupling reaction. Then, the intermediate product 9 and spermidine unit were cyclized through a dehydration reaction with $\mathrm{N}$ atom as linkage.

Cytoprotective effects of compounds 1-8 against hydrogen peroxide $\left(\mathrm{H}_{2} \mathrm{O}_{2}\right)$-induced cell death in $\mathrm{HepG}_{2}$ cell lines were evaluated using MTT method. The results of their cytoprotective properties are shown in Tables S4 and S5 (see ESI $\dagger$ ). Overall, compounds 1-8 exhibited moderate cytoprotective effects at $100 \mu \mathrm{g} \mathrm{ml} \mathrm{m}^{-1}$ against cytotoxicity induced by $\mathrm{H}_{2} \mathrm{O}_{2}$. The structure-activity relationship need to be further researched.

To confirm and evaluate the anti-apoptotic effects of these compounds, we selected compound $\mathbf{1}$ (C1) as test molecular and

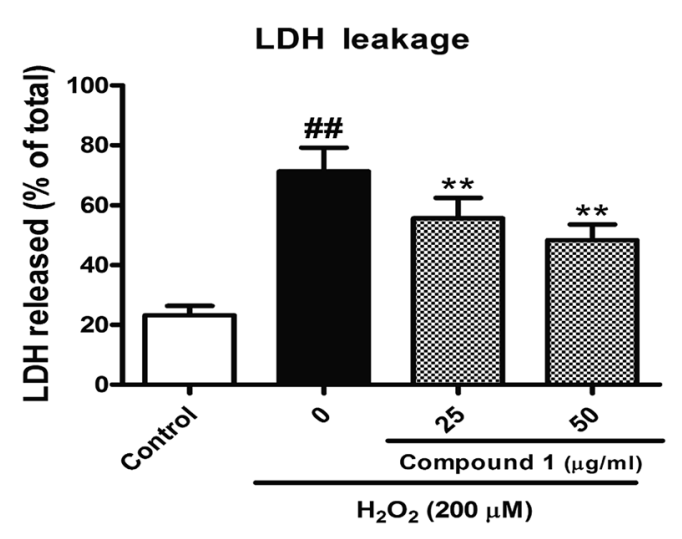

Fig. 4 Measurement of lactate dehydrogenase (LDH) release.

\section{Caspase-3 activity}

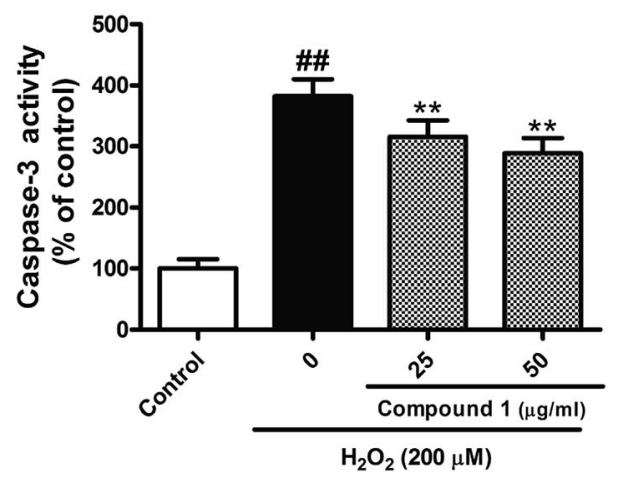

Fig. 5 Caspase- 3 activity determination. 


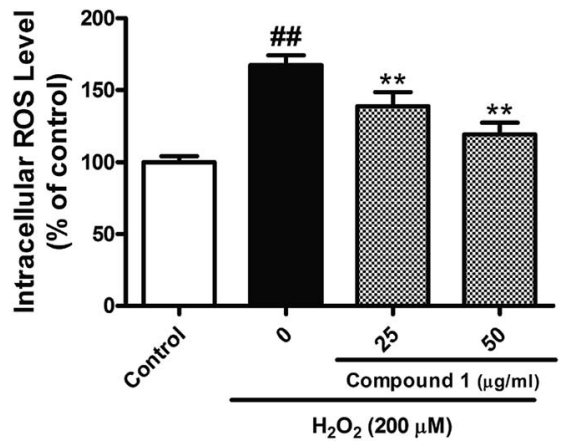

Fig. 6 Measurement of intracellular ROS.

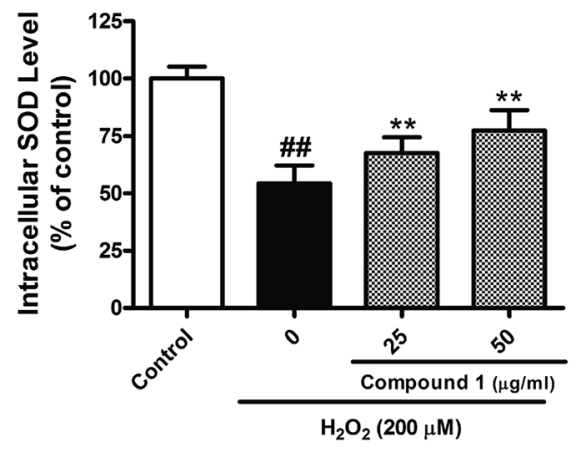

Fig. 7 SOD assay.

determined the $\mathrm{C} 1$ induced neuroprotection with the $\mathrm{LDH}$ release assay. As depicted in Fig. 4, exposure to indicated concentration C1 reversed $\mathrm{H}_{2} \mathrm{O}_{2}$-induced elevation of the levels of $\mathrm{LDH}$ release, which demonstrated $\mathrm{C} 1$ attenuated $\mathrm{H}_{2} \mathrm{O}_{2}$-caused cell damage. Simultaneously, we took the caspase- 3 activity assay to further confirm the anti-apoptotic effects of $\mathrm{C} 1$ in $\mathrm{H}_{2} \mathrm{O}_{2}$-damaged HepG2 cells. As shown in Fig. 5, $\mathrm{H}_{2} \mathrm{O}_{2}$ significantly increased the caspase-3 activity, while $\mathrm{C} 1$ reversed this tendency and showed the dosedependent manner. The down-regulation of $\mathrm{LDH}$ release confirmed the dramatic neuroprotective activity of $\mathrm{C} 1$, and the attenuated caspase-3 activity suggested the pro-apoptotic effect of C1.

Excessive ROS levels could initiate the perturbation of cellular redox balance and induce damage to major macromolecules in cells. In order to elaborate the close connection between the $\mathrm{H}_{2} \mathrm{O}_{2}$ induced injury and oxidative stress, we measured both oxidant and antioxidant parameters. Our results suggest that treated HepG2 cells with $\mathrm{H}_{2} \mathrm{O}_{2}$ could significantly increase the level of ROS with accompanying decrease in the activities of SOD. However, C1 could significantly alleviate such situation by dropping out the level of ROS (Fig. 6), as well as enhancing the activities of SOD (Fig. 7). It was suggested that C1 suppressed oxidative stress induced by $\mathrm{H}_{2} \mathrm{O}_{2}$ via both direct and indirect antioxidant actions.

\section{Conclusions}

In summary, eight new spermidine alkaloids (1-8) with moderate cytoprotective properties were isolated from the seeds of $O$. violaceus. The cellular mechanism for cytoprotection were the pro-apoptotic effect and antioxidant actions. Future studies are needed to focus on the cytoprotective activities of spermidine alkaloids from $O$. violaceus and clarify their structureactivity relationship.

\section{Acknowledgements}

The work was financially supported by the Technological Large Platform for Comprehensive Research and Development of New Drugs in the CAMS Innovation Fund for Medical Science (CIFMS) (Grant No. 2016-I2M-1-012), the Twelfth Five-Year "Significant New Drugs Created" Science and Technology Major Projects (No. 2012ZX09301-002-001-026), the National Science and Technology Support Program (No. 2012BA127B06), the Beijing Natural Science Foundation (No. 7164281), and the PUMC Youth Fund (No. 3332015141).

\section{Notes and references}

1 T. Y. Zhou, K. J. Guan and R. L. Guo, Science Press, 1987, 33, 40-43.

2 L. Xiao and P. Luo, Acta Bot. Boreali-Occident. Sin., 1994, 14, 237-241.

3 P. Luo, B. Q. Huang, J. M. Yin, Z. L. Chen, Y. H. Chen and Z. Q. Lan, Genet. Resour. Crop Evol., 1998, 45, 491-494.

4 Q. J. Ren, J. P. Yu and G. L. Zhang, Chinese Wild Plant Resources, 1998, 2, 24-25.

5 D. B. Weng and X. F. Huang, Acta Bot. Boreali-Occident. Sin., 2001, 21, 673-677.

6 P. Luo, Z. Q. Lan and Z. Y. Li, Plant Breed., 1994, 113, 83-85.

7 Y. Y. Wu, A study of the inorganic nutrition mechanism of Orychophragmus violaceus's adaptability to karst, in Comprehensive Studies on Plants of Adaptability to Karst -Orychophragmus violaceus, ed. Y. Y. Wu, Guizhou Sci. Publ. House, Guiyang, 1997, pp. 29-35.

8 D. B. Weng, H. F. Wang and J. Y. Weng, Chinese Wild Plant Resources, 2000, 19, 13-15.

9 Y. Y. Wu, Anticancer substance glucoraphanin new resources-Orychophragmus violaceus, in 2002 Innovative Excellent Achievement of Medicine in the World, Academie Européenne de Sciences Naturelles, Engelhardt-Ng Verlag, Bonn, 2002, pp. 62-63.

10 M. X. MA and Y. Mei, J. Anhui Agric. Sci., 2012, 40, 51095113.

11 T. T. Zhang, G. X. Ma, F. Q. Xu, J. N. Wu, X. P. Zhang and J. S. Yang, Chin. Pharm. J., 2014, 49, 2165-2167.

12 Y. W. Zhan, Z. Q. Xu, X. H. Guo, R. J. Li, J. P. Shen, X. D. Xu and B. X. Zhang, Chin. J. Pharmacol. Toxicol., 2016, 30, 101-106.

13 R. W. Doskotch, A. B. Ray and J. L. Beal, Chem. Commun., 1971, 300-301.

14 A. B. Ray, W. Kubelka, E. H. Fairchild, C. D. Hufford and J. L. Beal, Tetrahedron, 1974, 30, 3229-3236.

15 M. Khatib, G. Pieraccini, M. Innocenti, F. Melani and N. Mulinacci, J. Pharm. Biomed. Anal., 2016, 123, 53-62.

16 Y. Forster, A. Ghaffar and S. Bienz, Phytochemistry, 2016, 128, 50-59. 